\title{
COORDINATION MECHANISMS OF COLLABORATIVE R\&D PROJECTS IN SMALL AND MEDIUM ENTERPRISES
}

\author{
DANIELA BAGGIO AND DOUGLAS WEGNER \\ Universidade do Vale do Rio dos Sinos (Unisinos) \\ GUSTAVO DALMARCO \\ Pontifícia Universidade Católica do Rio Grande do Sul (PUCRS)
}

To cite this paper: Baggio, D., Wegner, D., \& Dalmarco, G. (2018). Coordination mechanisms of collaborative R\&D projects in small and medium enterprises. Revista de Administração Mackenzie, 19(2). doi:10.1590/1678-6971/eRAMR180095

Submission: Sep. 01, 2017. Acceptance: Dec. 19, 2017.

\section{(cc) $\mathbf{B Y}$} This is an open-access article distributed under the terms of the Creative Commons Attribution License.

\footnotetext{
This paper may be copied, distributed, displayed, transmitted or adapted if provided, in a clear and explicit way, the name of the journal, the edition, the year and the pages on which the paper was originally published, but not suggesting that RAM endorses paper reuse. This licensing term should be made explicit in cases of reuse or distribution to third parties. It is not allowed the use for commercial purposes.

Este artigo pode ser copiado, distribuído, exibido, transmitido ou adaptado desde que citados, de forma clara e explícita, o nome da revista, a edição, o ano e as páginas nas quais o artigo foi publicado originalmente, mas sem sugerir que a RAM endosse a reutilização do artigo. Esse termo de licenciamento deve ser explicitado para os casos de reutilização ou distribuição para terceiros. Não é permitido o uso para fins comerciais.
} 


\section{ABSTRACT}

Purpose: To analyze how small and medium enterprises (SMEs) coordinate collaborative research and development (R\&D) projects through an open innovation strategy.

Originality/value: This research was motivated by a theoretical gap in the management of collaborative $R \& D$ projects in open innovation strategies. The originality of the paper is to advance the understanding of coordination mechanisms that SMEs can use to manage open innovation and obtain more effective results.

Design/methodology/approach: The research followed a qualitative approach, through three case studies of collaborative projects. Data were collected by means of in-depth interviews with eleven managers directly involved in collaborative $\mathrm{R} \& \mathrm{D}$ projects.

Findings: Results demonstrate that the use of coordination mechanisms depends on the applicability of each project's results, i.e., the higher the chances of a certain $R \& D$ project becoming a real product, the higher the importance given to the coordination mechanisms. On the cases observed, the coordination mechanisms were defined by the enterprise, not by external partners. In addition, it was observed that open innovation projects that the enterprise seeks for external knowledge to complement internal resources (outside-in) were considered more important than transferring internal knowledge to external partners (inside-out). The paper contributes to organizational theory by highlighting the relation between the characteristics of collaborative $R \& D$ projects and the coordination mechanisms used. Regarding the managerial contribution, results serve as a guide for entrepreneurs and managers of SMEs interested in coordinating collaborative projects based on open innovation processes.

\section{KEYWORDS}

Coordination mechanisms. Open innovation. Collaborative practice. Research and development. Small and medium-sized enterprises. 


\section{INTRODUCTION}

In the last decades a consensus on the importance of innovation for business competitiveness and survival has been developed (Rasera \& Balbinot, 2010). Historically, large enterprises performed research and development (R\&D) activities internally, creating and managing large laboratories that would generate advantage over their competitors (Freeman, 1992). Although researchers sought knowledge from external sources, the risk of developing new technologies with partners led enterprises to focus their innovation activities internally on a model characterized as closed innovation (Chesbrough, 2012). For small enterprises, this was a difficult-to-compete scenario, given their limitations for investing in laboratories and R\&D projects.

However, with rising competitiveness, speed and costs of developing new technologies, many enterprises lack the size, resources and skills to innovate (Hasnas, Lambertini, \& Palestini, 2014). The need to complement internal resources and share the risks of technological development has led the innovation activity to a new level - from a closed model to the open innovation model (OI). Open Innovation is defined by the use of information and knowledge internal and external to the organization for the development of innovations, mainly through partnerships with other organizations (Chesbrough, 2012). With the OI model, SMEs may seek cooperation with other agents (mainly clients and suppliers, but also universities and applied research centers), boosting technological development and offering new products and services (Brunswicker \& Vanhaverbeke, 2015).

Here, innovation emerges through an interactive process of creating and applying knowledge, involving both the business environment - customers, suppliers and competitors - and the academic field - universities, research centers and training centers (Tödtling, Lehner, \& Kaufmann, 2009). Borini, Pereira, and Rosseto (2016), based on data from PINTEC (Instituto Brasileiro de Geografia e Estatística [IBGE], 2016), state that in Brazilian universities, training centers and competitors are the main partners of enterprises seeking to develop innovative projects ${ }^{1}$. Although innovation activities are limited in Brazil, this demonstrates that enterprises do pursue the complementation of their competence for technological development projects through partnerships.

PINTEC (IBGE, 2016) surveyed 128,699 Brazilian companies, of which $98.3 \%$ are micro, small and medium-sized enterprises. The same survey also shows that out of the companies that innovated in product or process, $97.3 \%$ are micro, small and medium enterprises. 
Recent studies have examined the implementation of open innovation practices by enterprises (Vrande, Jong, Vanhaverbeke, \& Rochemont, 2009; Dahlander \& Gann, 2010; Chiaroni, Chiesa, \& Frattini, 2011; Carvalho \& Sugano, 2016), evaluating its impact on the performance of companies of different sizes (Spithoven, Vanhaverbeke, \& Roijakkers, 2013), and the different strategies of knowledge acquisition and appropriation (Brunswicker \& Vanhaverneke, 2015; Freel \& Robson, 2016). However, it is not clear in these and other studies which are the mechanisms used in the coordination of collaborative R\&D practices, especially in the context of SMEs. SMEs are important ventures for job and income generation (Barbosa \& Musetti, 2012) and traditionally face limitations in resources to invest in $R \& D$ (Escrivão Filho, Albuquerque, Nagano, \& Oliveira, 2017).

Based on such gap this paper aims to analyze how the coordination of collaborative innovation practices in the process of Open Innovation in SMEs occurs. The internal context of enterprises for the adoption of OI strategies is an aspect that still needs to be addressed (Huizingh, 2011). Simultaneously, a limited number of studies analyzes OI in SMEs (Wynarczyk, Piperopoulos, \& McAdam, 2013), this being one of the trends of application of the Open Innovation concept (Gassmann, Enkel, \& Chesbrough, 2010).

The paper is divided into six sections. After the introduction, the literature review is presented. The third section describes the methodological procedures, followed by results and discussion in the fifth section. In section six, the study's contributions and conclusion are presented.

\section{COLLABORATION IN R\&D}

Collaboration between different organizations is defined as an interorganizational relationship, in which the objective is to improve partners' competitiveness (Phillips, Lawrence, \& Hardy, 2000). Collaboration comes through a series of ongoing relationships (Håkansson, 1990) and can emerge through sub-contracting, franchising, consortia, alliances, joint ventures, networks and associations (Hardy, Phillips, \& Lawrence, 2003). However, enterprises have not always considered collaboration as a strategy for the development of innovations. The option was to develop research internally, thus protecting the new knowledge that was being generated. This model is known as Closed Innovation (Chesbrough, 2012).

In the last decades the closed innovation model has proved insufficient for the context of competitiveness and the need to accelerate technological 
development. Even large enterprises, with significant R\&D budget, have sought opportunities in partnerships with universities and research centers to complement the development of new technologies (Pavitt, 1992), leading to the open innovation model. OI is characterized by the expansion of outsourced knowledge, accelerating the innovation process (Hasnas et al., 2014) and broadening the forms of interaction with the end consumer (Chesbrough, 2012). Open innovation offers access to a wide range of ideas and knowledge (Laursen \& Salten, 2006), making it possible to use unprecedented solutions to current problems (Nuvolari, 2004).

Two processes can be identified by enterprises applying the OI concept: the process from inside-out and outside-in (Dahlander \& Gann, 2010; Vanhaverbeke \& Chesbrough, 2014). The inside-out process is characterized by trading the internal knowledge generated by an enterprise; that is not being used or out of line with its business model (Keupp \& Gassman, 2009; Chiaroni et al., 2011). This process, more common among large enterprises with high investments in $R \& D$, foresees the generation of profit for the enterprise through the licensing of patents and the creation of spin-off companies, among other initiatives (Christensen, 2001; Enkel, Gassman, \& Chesbrough, 2009).

On the other hand, the outside-in process consists of acquiring knowledge and technology for the development of innovation internally (Keupp \& Gassman, 2009). It is the practice of establishing relationships with external organizations to access their technical and scientific competence, complementing the enterprise's internal assets (Chiaroni et al., 2011). In this model, the enterprise's knowledge platform is expanded through the internalization of know-how, prototypes, patents or even startups with existing products in emerging markets (Jong, Vanhaverbeke, Kalvet, \& Chesbrough, 2008; Enkel et al., 2009; Vanhaverbeke \& Chesbrough, 2014; Brunswicker \& Vanhaverbeke, 2015). The application of open innovation by SMEs is discussed by Vrande et al. (2009) and Rados and Bozic (2012), who state that the association with external partners can increase the efficiency of these enterprises in the development of innovation, as this partnership complements their internal competence.

However, the success of such cooperation depends on the coordination of collaborative activities between partners. Enterprises that engage in open innovation activities are subject to risks and barriers such as loss of knowledge, costs of coordinating external agents, and loss of control over patents (Enkel et al., 2009; Vanhaverbeke \& Chesbrough, 2014). Therefore, the success of open innovation practices is directly linked to the coordination mechanisms of interorganizational relationships. 


\subsection{Coordination Mechanisms}

Interorganizational relationships can occur through a wide variety of formats and objectives (Cropper, Ebers, Huxham, \& Smith-Ring, 2008), from the pursuit of gains in scale and market power to access to new markets and the development of new products (Ring \& Van de Ven, 1994). The greater the heterogeneity of knowledge amongst partners, the greater the potential for innovation outcome (Rodan \& Galunic, 2004). To explore the possibilities of open innovation through interorganizational relationships, it is necessary to implement coordination mechanisms that allow optimizing the results of these partnerships. Thus, Grandori and Soda (1995) proposed a set of ten mechanisms for the coordination of interorganizational relations, exploring the nature of these mechanisms and their singularities.

The first mechanism refers to communication practices, decisionmaking and negotiation among those involved. This mechanism stands out because it is less onerous, being present in all types of relations. Repeated negotiation meetings contribute to the partners in a transaction to observe the superiority of the collective benefit (Axelrod, 2010). In addition, the proximity provided in working teams is essential for sharing organizational knowledge (Dyer \& Nobeoka, 2000).

The second mechanism refers to social coordination and control. This mechanism aims to establish relationships of trust through a set of group norms, reputation and control of partners. It is directly related to the reciprocity between players (Brass, Galaskiewicz, Greve, \& Tsai, 2004).

The third mechanism consists of horizontal inter-unit integration. This mechanism represents the design and organization of network relationships involving both internal and external agents (Grandori \& Soda, 1995). Horizontal integration reduces deadlocks between organizations and facilitates the decision-making process, especially in the development of new projects (Seran, Pellegrin-Boucher, \& Gurau, 2016).

Common staff refers to the fourth coordination mechanism. When the scope of cooperation and the volume of activities become significant, structuring and setting a specific team may be necessary (Grandori \& Soda, 1995). The structuring and coordination of interorganizational teams optimizes the maintenance and transfer of knowledge between partners, being important for the network operation (Manning, 2017). This mechanism establishes not only the coordination of activities carried out by collaborating enterprises, but also the information that will be shared between them.

The fifth mechanism refers to hierarchical and authority relations. Although they are composed of legally independent players, 
interorganizational networks and partnerships can accept the leadership of a single enterprise as a coordination mechanism (Lorenzoni \& Ornati, 1988). The mechanism can be formal, through contracts and processes monitored by structured systems, or use non-hierarchical mechanisms, such as lateral negotiation and communication, decision-making groups and working teams (Grandori \& Soda, 1995).

Control and planning systems refer to the sixth mechanism. Cooperation brings the challenge of promoting collaborative behavior and avoiding opportunism. The control through monitoring and results tracking system is more efficient than behavioral supervision, since it considers a series of defined actions necessary to achieve organizational goals (Grandori \& Soda, 1995). These mechanisms also complement knowledge acquisition and sharing among cooperative agents, optimizing the results delivered (Vlaar, Van Den Bosch, \& Volberda, 2007; Nooshinfard \& Nemati-Anaraki, 2014).

The seventh mechanism refers to incentive systems. This type of mechanism is used in the development of complex activities, aiming to optimize the participation of those involved in high risk projects (Grandori \& Soda, 1995). One way to promote incentives is through the use of formal contracts, addressing the rules for a fair sharing of benefits, avoiding opportunistic actions and the need for contractual guarantees (Williamson, 1985).

As an eighth mechanism, Grandori and Soda (1995) highlight the selection system. This coordination mechanism seeks to select potential partners to be connected to the network, in order to increase chances of conducting collaborative activity. The selection system consists of a determining criterion - such as common objectives, complementary capabilities and process coherence - to find the right partners and reduce divergences.

The ninth mechanism refers to information systems. Information systems act as important vertical integration mechanisms within enterprises, since they reduce communication costs (Grandori \& Soda, 1995). Information technology assists in coordination efforts by disseminating information rapidly and is a frequently applied management tool (Dodgson, Gann, \& Salter, 2006).

In turn, the tenth mechanism refers to public support and infrastructure. According to Grandori and Soda (1995), and Noteboom (1996), this mechanism can be used to foster cooperation in order to bring in benefits. However, this type of cooperation is difficult to be obtained due to the high investment required and the low appropriation of benefits.

Based on the ten coordination mechanisms of interorganizational activities proposed by Grandori and Soda (1995), and in open innovation processes (Chesbrough, 2012), this paper proposes to identify how the 
coordination of collaborative $\mathrm{R} \& \mathrm{D}$ practices in the OI process of SMEs occurs. So, the next section describes the methodological procedures adopted to achieve the objectives presented.

\section{METHODOLOGICAL PROCEDURES}

The research aimed to analyze how Brazilian SMEs perform coordination of collaborative R\&D practices based on OI strategy. For this purpose, the definition of SMEs by Brazilian Service of Support to Micro and Small Enterprises (Sebrae) was used, which categorizes the size of an enterprise according to the number of employees. Industries with up to 19 employees are considered micro-companies; between 20 and 99 employees are considered small companies, and 100 to 499 employees are considered medium-sized companies (Serviço Brasileiro de Apoio às Micro e Pequenas Empresas [Sebrae], 2013).

We performed a multiple case study with qualitative approach to reach our goal. This type of method is recommended when it aims to analyze in depth a certain trend (Triviños, 1987). The selection of cases was based on the following criteria: 1 . enterprises in the industry sector that have performed some collaborative $\mathrm{R} \& \mathrm{D}$ project in the two years prior to the research; 2. that have less than 499 employees, being configured as a small or medium-sized company. The first criteria aimed to select recent collaborative projects, favoring the description of the coordination mechanisms used.

Based on contacts with managers of technology parks in the metropolitan region of Porto Alegre (RS), three collaborative projects were indicated that met the criteria, resulting in 11 in-depth interviews (Figure 3.1).

\section{(Figure 3.1)}

\section{CASES ANALYZED AND THEIR RESPONDENTS}

\begin{tabular}{|c|c|c|c|}
\hline Project and Objective & Partners & Sector of the market & Respondents job title \\
\hline \multirow{2}{*}{$\begin{array}{l}\text { (P1): } \\
\text { To manufacture } \\
\text { supplies for burn } \\
\text { wound dressings. }\end{array}$} & Enterprise $1 \mathrm{~A}$ & $\begin{array}{l}\text { Footwear, automotive, } \\
\text { medical-hospital and } \\
\text { security. }\end{array}$ & - Partner and Industrial Director \\
\hline & Supplier 1B & $\begin{array}{l}\text { Production of nano- } \\
\text { technological inputs. }\end{array}$ & - Partner and Technical Director \\
\hline
\end{tabular}




\section{(Figure 3.1 (conclusion))}

CASES ANALYZED AND THEIR RESPONDENTS

\begin{tabular}{llll}
\hline Project and Objective & \multicolumn{1}{c}{ Partners } & \multicolumn{1}{c}{ Sector of the market } & \multicolumn{1}{c}{ Respondents job title } \\
\hline \multirow{2}{*}{$\begin{array}{l}\text { (P2): To produce a } \\
\text { chip with specific } \\
\text { characteristics. }\end{array}$} & Enterprise 2A & $\begin{array}{l}\text { Electronic, mechanical } \\
\text { and software. }\end{array}$ & - Partner and Technology Director \\
\cline { 2 - 4 } & Enterprise Partner 2B & $\begin{array}{l}\text { Technology, chip and } \\
\text { semiconductor } \\
\text { development. }\end{array}$ & $\begin{array}{l}\text { - Chief Executive Officer } \\
\text { - Technical director } \\
\text { - Project Manager }\end{array}$ \\
\hline & Enterprise 3A & Industry & - Project coordinator \\
\cline { 2 - 4 } $\begin{array}{l}\text { (P3): To create } \\
\text { solutions in } \\
\text { educational products } \\
\text { considering } \\
\text { accessibility to } \\
\text { impaired people. }\end{array}$ & University 3B & Education & - Advisor for Inclusive Actions \\
\cline { 2 - 4 } & University 3C & Education & - System User and disabled person \\
\cline { 2 - 4 } & Middle school 3D & Education & - Teacher of impaired students \\
\hline
\end{tabular}

Source: Elaborated by the authors.

The projects were organized in the order which interviews took place, being listed as P1 (project 1), P2, and P3. In each project, the enterprise leading open innovation practices was defined as $1 \mathrm{~A}$ (project enterprise 1 ), $2 \mathrm{~A}$, and $3 \mathrm{~A}$. Also, the other participating organizations were identified by the project number followed by the subsequent letter in the alphabet (1B in project 1, $2 \mathrm{~B}$ in project 2 etc.)

\subsection{Research protocol}

Using the concepts described in the theoretical framework, the case study protocol was developed, which was aimed at guiding data collection (Yin, 2001). The interview script applied in this research was semistructured, composed of three blocks and totaling 26 questions. The blocks are: six questions on the characterization of the enterprise and its respondents; six questions on collaborative practices; and 14 questions on coordination mechanisms.

The interview script was set up and validated by three experts in the area, following recommendations of Malhotra, Birks, and Wills (2012). 
External validation was carried out with three entrepreneurs, to verify if content was clear and would not generate constraints when responding.

Before carrying it out, a pilot case was performed. Using the same case selection criteria for the study, a collaborative project between a manufacturer and its supplier to develop a homeware piece was chosen. The pilot case deals with a project directed to the furniture sector and data collection acquired from representatives of each enterprise, both based in the city of Bento Gonçalves (RS).

From the pilot case, the research protocol underwent some modifications in questions 8, 9 and 13, because managers found them extensive and confusing. These issues were adjusted for better understanding and they relate to the mechanisms Common Staff ("Is there a common staff team responsible for the collaborative practice? How does it operate?"), Hierarchical and Authority Relationships ("How do you manage the coordination of parties involved in the collaborative practice?"), and Control and Planning Systems ("What controls are used to ensure a partner acts according to the joint planned goals?"). After the suggested adjustments were made, data collection started.

\subsection{Data Collection and Data Analysis Procedures}

The interviews were conducted individually via Skype, using a digital recorder and later transcription of data. The respondents were selected according to their involvement with the collaborative project, favoring the access to detailed information about coordination mechanisms used. The interviews lasted an average of one hour and twenty minutes and in some cases a new contact was made by e-mail for clarification or supplementary information. The data collection also relied on the use of secondary data such as the participating enterprises' corporate website and documents made available by respondents.

A qualitative data content analysis was performed (Bardin, 1995), following the steps proposed by Minayo (2000). First, data was ordered by mapping all information obtained, involving the transcription of recordings, reading material and organizing secondary data. Then data was categorized according to the coordination mechanisms described in the literature review. Finally, the final analysis was carried out, articulating the collected data with the theoretical framework elaborated. 


\section{RESULTS}

\subsection{Collaborative Project 1: Enterprise-Supplier}

The first case study covers the category of OI practices from outside the enterprise. This collaborative practice is described by an enterprise and its supplier and refers to the generation of knowledge through external organizations know-how and the development of prototypes. The project was carried out by the Enterprise 1A, located in a technological park in the municipality of Campo Bom (RS). The supplier company $1 \mathrm{~B}$, partner of the collaborative project, is located in a technological park in the city of Florianópolis. The collaborative practice began with appointing a researcher who has previously provided consulting services for enterprise $1 \mathrm{~A}$ and who also indicated the supplier company, whose partner and founder was his student.

This project had as objective to manufacture supplies for dressings on burns. The partners developed a nano-functionalized tissue, with prolonged release of antimicrobial, anti-inflammatory, analgesic and scar healing function, produced with carrageenan. The fabric is intended for burns wounds dressings and postoperative procedures.

\subsubsection{Coordination Mechanisms in P1}

Of the coordination mechanisms analyzed in P1, the following stood out in the interviews: communication, decision-making and negotiation; incentive schemes; horizontal inter-unit integration; control and planning systems; and public support and infrastructure.

Communication between parties is carried out through e-mails, phone calls and face-to-face meetings. The executive of Enterprise 1A explains that frequency in the communication of the project relies very much on the phases in which it is found. The director of provider 1B also explains that: "Initially, meetings were set more frequently. Then the project was sent to the Financier of Studies and Projects (Finep) and while waiting for response no meetings were set in the meantime. After project approval, meetings took place every one or two months". The decisions and negotiations are carried out jointly, according to the evolution of the project and with equal autonomy for each partner. A team of researchers on each side participates in the negotiations and decisions related to the activities. The 1A director 
reports that "we have a schedule of when and how it will be done. Of course, however, we periodically hold meetings with the entire team to readjust the project on top of results and goals". Decisions are about product development, schedule, and project planning.

In the Incentive Scheme mechanism, 1B supplier director explains she can not guarantee the partner will behave in accordance with enterprise's expectations: "One way of trying to be more assertive is to evaluate partnering enterprises confidentiality, and project execution agreements delimit the objectives of projects and responsibilities of the parties involved". The project is governed by a contract of confidentiality and, in the event of any behavior that is in disagreement with the established, termination of the same can be requested.

In the interunit horizontal integration mechanism, enterprise $1 \mathrm{~A}$ board is responsible for the execution of the project with the supplier company. As it is evident in the speech by enterprise 1A director: "those responsible for this issue are the management of the enterprise, myself and my partner". Likewise, in the supplier company 1B there is a group of people who have this contact more directly with other enterprises, as the respondent reports: "the existence of an specific team to folllow up and handle the relationship between enterprises facilitates the monitoring of activities, increasing chances of partnership success".

As for the control and planning system, both enterprises carry out task planning by setting rules and defining activities. The director of supplier $1 \mathrm{~B}$ further explains that she drafts projects' schedule time and holds meetings to align deadlines so partners also follow the development of the planned activities: "Yes, it is extremely important that we have a plan in our projects and meetings with our partners". The director of Enterprise 1A explains that follow up technical spreadsheets are issued from the beginning of the process so that procedural and control errors are not made.

With respect to the public support mechanism and infrastructure, as mentioned previously, the project was funded by FINEP, enabling its development. In the same way, the monitoring of the development agency led enterprises to have more control over activities, more detailed planning, and better handling of deadline concerns. This stimulated the application of project management practices, qualifying both organizations to create a structure that can favor the development of new projects. As the 1A director explains: "We received a very good financial support from the government, and with all our planning we made very good use of it. It was essential for the development of our project". 


\subsection{Collaborative Project 2: Enterprise-Enterprise}

Case study 2 describes the category of OI practices from outside the enterprise. This collaborative practice is of an enterprise with a partner and refers to the transfer of know-how and patents. Enterprise $2 \mathrm{~A}$ is installed in a technology park in the municipality of Santa Cruz do Sul (RS). The enterprise started carrying out collaborative practices in R\&D in partnership with universities in 2005. The other partner is located in the municipality of Santa Maria (RS).

The collaborative practice started because one of the partners of enterprise 2A held existing contacts with the Federal University of Santa Maria, where he studied and met the CEO of enterprise 2B. The collaborative project (P2) aimed to produce a chip with specific characteristics, as explained by the director of enterprise $2 \mathrm{~B}$, "they wanted a chip, which is our micro controller, but with low power consumption". This project was financed by FINEP due to the degree of innovation in the development of new technology. The respondent comments that because of project risk it is difficult to obtain resources other than through public innovation bidding.

\subsubsection{Coordination Mechanisms in P2}

Among the coordination mechanisms analyzed in P2, respondents highlighted communication, decision making and negotiation skills, incentive schemes, horizontal inter-unit integration, control and planning systems, and public support and infrastructure.

Communication means between parties is done mainly through online tools, and eventually face-to-face meetings. The director of enterprise $2 \mathrm{~A}$ explains: "due to distance factor, our communication is basically done through e-mails, telephone and videoconferences". The frequency of communication was monthly, explains the $\mathrm{CEO}$ of 2B. However, the director of enterprise $2 \mathrm{~B}$ highlights that "as project demands have dropped a lot, we are holding meetings every two or three months". Negotiations and decisions regarding the project are all formalized to facilitate monitoring and control. The director of enterprise 2B explains: "Everything taken on and realized through projects are noted on minutes, emails and made official. Even conferences and conversations are formalized in an email so that everything is documented". The director of enterprise 2B also mentions, "Everything is done through a formal process, all documentation from both sides is taken and put on record". The $2 \mathrm{~B}$ project manager explains that "decisions are 
taken in a formal manner through meetings, but eventually decisions can be made informally".

As for the Incentive Systems mechanism, an intellectual property contract was observed in this project, which also governs partial project deliveries, as explained by enterprise $2 \mathrm{~A}$ director:

"We have a clause establishing fines on failures in project deliveries that penalizes the share over royalties [...] which will be charged upon future sale of products. In that case, instead of distribution of royalties being 50/50, it will be $80 \%$ for us and $20 \%$ for our partner, in addition to the payment of a fine. For example, the agreed upon product efficiency was $100 \%$ and only $80 \%$ was reached". Enterprise $2 \mathrm{~A}$ director adds "nothing is solved without contract, because it is company policy".

Regarding inter-units mechanism of horizontal integration, enterprise 2A management makes the connection of collaborative practices, according to the director: "I am responsible for the management of interaction between parties". Respondents from enterprise $2 \mathrm{~B}$ explain that because the enterprise is relatively small and the degree of complexity is large, two people are in charge of the collaborative practice.

As for the control and planning system, both enterprises carry out task planning by setting rules and defining activities. The director of enterprise 2A reports: "We did our planning by scheduling tasks and results to be achieved at each stage". As reported, the schedule and deliveries are related to the coordination and control mechanism, influencing the agreement of royalties and intellectual property.

The joint cooperation program received federal funding for the execution of the project and influenced its coordination (as described also in project 1). The director of enterprise 2A points out that "yes, we received financial support from the federal government, no doubt, it was very important for the realization of our project, because it requires very high figures". Due to this funding a greater control over the development of activities is necessary during the collaborative project. In addition, the fact that the enterprise was in a technology park favored the approach with the partner enterprise, demonstrating the importance of innovation ecosystems for contact and development of joint projects.

\subsection{Collaborative Project 3: Enterprise-Users}

The third case study looks into the category of OI practices from outside to within the enterprise, through the transfer of applied skills and know-how. 
This collaborative practice is from an enterprise with two universities and a school, as well as teachers and users. Enterprise 3A is located in the municipality of Santa Cruz do Sul (RS). It began conducting collaborative $R \& D$ practices with educational and private institutions because there was a desire to develop school products that meet the needs of people with disabilities. The company justifies the use of collaborative practices as it understands they increase chances of products being aligned with people's needs this way, and not only the point of view from the development team. "We could only make our projects come through this way, having many partners involved and working together making it easier to get there" (Project 3A Coordinator).

The Federal Institute of Education, Science and Technology of Rio Grande do Sul (IFRS), here denominated 3B, the Federal University of Rio Grande do Sul, (UFRGS), denominated 3C, and a school located in the municipality of Santa Cruz do Sul, called 3D, are the partners of the collaborative project. The project started in 2012 and the collaborative network has generated several innovations in products aimed at education of students with special needs, such as pen and pencil thickeners, fixed sharpeners on the table, adapted scissors and larger rubbers.

\subsubsection{Coordination Mechanisms in $\mathrm{P} 3$}

From the coordination mechanisms analyzed in P3, the interviews highlighted communication, decision making and negotiation skills, common staff teams and control, and planning systems.

Communication between the parties is carried out by phone calls, e-mails, whatsapp, teleconferencing, Facebook and face-to-face meetings. As for the frequency of communication between the parties, respondents mentioned having daily contact according to project's demands. Respondents explain that negotiation and decision making are usually formal and always taken together. Both teachers and the school administrative board are involved in the decision-process, adding to the students' parents, who are the final users of the technologies developed. This is evidenced in the interview of the university $3 \mathrm{C}$ respondent: "decisions related to joint events and workshops are made with all stakeholders at meetings". The 3D school teacher adds: "All schools, teachers and some parents involved try out the products and then some decisions are made, for example, the pencil should be thicker, or the glue is not sticking as it should".

As for the common staff mechanism, 3C University respondent explains that there is a specific team in charge of the project: "We have a team in the 
virtual accessibility project, developing solutions from low cost assistive technologies to methodologies, practices and production strategies adapted to impaired students".

Project coordinator 3A explains the control and planning systems mechanism "We have a wide scope planning not to lose sight of the project objective. But many of the ideas in mind are designed and experienced by people". The project does not aim at a single technology, but rather uses the relationship with partners as a source of ideas and experiences for different possibilities of products and services. Planning and control is paramount for a long-term partnership, constantly motivating those involved.

\section{DISCUSSION OF RESULTS}

The results demonstrate that open innovation practices discussed in the projects studied are concentrated outwardly evidencing enterprises explore only part of the possibilities of broadening innovation process (Figure 5.1).

(Figure 5.1)

COMPARISON OF OI PRACTICES BETWEEN CASES

\begin{tabular}{llll} 
& \multicolumn{1}{c}{ Project 1 } & \multicolumn{1}{c}{ Project 2 } & \multicolumn{1}{c}{ Project 3 } \\
\hline Ol process & Outside - In & Outside - In & Outside - In \\
\hline Type of knowledge & $\begin{array}{l}\text { Know-How } \\
\text { Prototypes }\end{array}$ & $\begin{array}{l}\text { Know-How } \\
\text { Patents }\end{array}$ & Know-How \\
\hline
\end{tabular}

Source: Elaborated by the authors, based on Vanhaverbeke and Chesbrough (2014) and Keupp and Gassman (2009).

As Figure 5.1 demonstrates, two distinct types of knowledge transfer were observed: 1 . informal knowledge gained from partners' experience (described by know-how); and 2. technologies already developed and tested (described by prototypes and patents). The transfer of know-how is inherent to partnerships, because in project alignment meetings, knowledge acquired from each partner is presented and discussed by both parties. Technologies, on the other hand, are characteristic of the types of project; therefore, described only in cases 1 and 2 that predicted the development of new products. The results confirm the findings of Jong et al. (2008), who affirm exchange of experiences is one of the motivations of SMEs to get involved in 
joint projects. Brunswicker and Vanhaverbeke (2015) complement that interactions of SMEs with partners focused on technology or knowledge utilization offer more benefits to the enterprise as they are more likely to become innovative.

However, knowledge transfer from inward-out was not observed, showing a limitation in the analyzed cases. Although the inward process is considered important by enterprises that want to strengthen their R\&D activities, the reverse process was not perceived by these enterprises as advantageous or possible at this time. As Dahlander and Gann (2010) argue, enterprises can be extremely protectionist with internal knowledge, restricting the process from the inside out. In SMEs this process is even more limited (Vrande et al., 2009).

Describing the coordination mechanisms used by the cases analyzed, communication, decision making and negotiation; horizontal inter-unit integration; common staff team; control and planning systems; and public support and infrastructure were noticed (Figure 5.2).

\section{(Figure 5.2)}

COMPARISON OF COORDINATION MECHANISMS BETWEEN CASES

\begin{tabular}{|c|c|c|c|}
\hline Type of mechanism & Project 1 & Project 2 & Project 3 \\
\hline Decision making and negotiation & $x$ & $x$ & $x$ \\
\hline Social Coordination and Control & Not observed & Not observed & Not observed \\
\hline Horizontal inter-unit integration & $x$ & $x$ & Not observed \\
\hline Common staff team & Not observed & Not observed & $x$ \\
\hline Hierarchical and authority relations & Not observed & Not observed & Not observed \\
\hline Control and planning systems & $x$ & $x$ & $x$ \\
\hline Incentive system & $x$ & $x$ & Not observed \\
\hline Selection system & $x$ & $x$ & $x$ \\
\hline Information system & Not observed & Not observed & Not observed \\
\hline Public support and infrastructure & $x$ & $x$ & Not observed \\
\hline
\end{tabular}

Source: Elaborated by the authors.

As seen in Figure 5.2, communication, decision making and negotiation mechanisms; control and planning systems, and selection systems were 
observed in all three cases, demonstrating their importance in OI projects. As reported by respondents, the mechanism of communication, decision making, and negotiation is paramount for the start and operation of the project. The more knowledge is shared between partners, the easier is the decision-making process. In addition, communication routines and negotiation, and decision-making processes favor project follow-up by the different partners, thus allowing differences in opinions over the progress of a project and partial goals, addressing individual objectives.

In turn, the Control and Planning Systems mechanism was operationalized through the definition of project schedule, enabling partial deliveries and, consequently, the finalization of the project. This mechanism is also inherent in project execution, being considered clearly important by the respondents. This result is in line with the findings of Nooshinfard and Nemati-Anaraki (2014), which point out the complexity of knowledge sharing between organizations, and consequently the importance of control and planning mechanisms. As mentioned in the results, control and planning mechanisms are influenced by the mechanisms of communication and decision, since the second will define a proper schedule for the first.

Regarding the other mechanisms adopted, the differences are related to project objectives: projects 1 and 2 have very clear objectives, focused on the development of a specific product. There are goals for partial results; transfer agreement and intellectual property, in addition to federal funding received due to their innovative character. So, incentive systems, horizontal integration, inter-units mechanisms, federal funding and infrastructure are relevant in these projects. As stated by Brass et al. (2004), the need for control among partners is related to their interdependence, which is fundamental in innovation projects. Similarly, Seran et al. (2016) refer to the importance of horizontal integration (another control mechanism) for decision-making in innovation projects. Finally, projects 1 and 2 are supported by federal funding mechanism and infrastructure, adding to the fact public development can foster cooperation, especially in innovation ecosystems such as technology parks and incubators (Etzkowitz, Solé, \& Piqué, 2007).

The characteristic of project 3 favored the use of common staff team mechanism. Unlike the mechanism of horizontal integration inter-units, in this case there is a specific team, and not the integration between teams. These mechanisms emerge in Project 3 because of the particular characteristics of the collaboration, which aims an approach with partners to discuss possibilities and applications of new products in a specific market. This is in line with Manning's (2017) findings, which underscore the importance of interorganizational teaming for knowledge sharing between partners. 
Three coordination mechanisms originally proposed by Grandori and Soda (1995) were not observed in the projects: Social Coordination and Control, Hierarchical and Authority Relationships and Information Systems. In relation to the mechanism Social Coordination and Control, it is believed that short term projects do not develop rules and shared identity, which characterize the use of such mechanisms. In turn, a possible explanation for the absence of the Information Systems mechanism is the temporary nature of the projects, which would not justify the development or use of a dedicated information system or specific software for partner interaction. Communication through traditional channels like telephone, email and whatsapp suited this type of project need. As for the mechanism Hierarchical and authority relations, such is used in contexts where there is a leader enterprise or with greater legitimacy to take control. In the three projects analyzed, horizontal and collaborative relations were observed without the predominance of one enterprise's only authority.

Some difficulties in the execution and implementation of the projects emerged in the interviews, even though this aspect was not one of the objectives of this research. The main difficulty described by respondents was in royalty's negotiation. This is a sensitive matter in negotiations between enterprises and universities, as enterprises usually understand they do not have to pay royalties for projects they are developing. Universities, in turn, make a point of collecting royalties since they contribute with their own know how in the project. Flexibility and, especially, clarity over intellectual property rules from both parties is the key to minimize deadlocks. Another difficulty mentioned in project 2 was the delay in the transfer of funds from FINEP, which led to delays in the project and the need for extra investment by the enterprise.

\section{FINAL CONSIDERATIONS}

In Brazil, the development of innovation in product or process is limited to $36 \%$ of enterprises (IBGE, 2016). This number is even smaller in the context of SMEs, as such enterprises have very low R\&D incentive schemes. In this sense, the results of this paper demonstrate possible manners to overcome these hardships by opening up the innovation process. The open innovation practices presented in this paper highlight the existing opportunities, both for knowledge sharing stimulated by projects funded with government resources, and for the information of potential clients as a 
source of product ideas. Even with a limited number of cases, the evidence demonstrates that SMEs can use open innovation practices as a complement to their new product development processes.

Analyzing the open innovation process, the cases show they are at different stages of OI implantation. Case 3 is the most initial, using only one channel to obtain information from clients and users, capturing ideas and testing prototypes through a group of discussions of new technologies described here by the transfer of applied knowledge. In this case, there are no specific objectives, demanding more efforts from the enterprise to keep this group active, generating new and relevant information. This demonstrates that in the case studied, even without a large budget or a high level technological project, OI practices helped the enterprise benefited by case 3 in the development of new products. In turn, cases 1 and 2 are already somewhat more advanced in the implementation of OI process, since they work with the transfer of prototypes and patents - activity widely described as a reference in OI strategies.

In relation to the main objective of the paper, it was verified that there are differences between projects regarding the use of coordination mechanisms. Projects 1 and 2 present common characteristics of formal research projects, supported by public development funds. They have a defined schedule, followup meetings, technology transfer contracts, work teams in each of the participating enterprises, and established communication tools. Project 3, because of its collaborative characteristic, although with well-defined monitoring and communication structures ("for the project not to die", as one of the respondents said), fit a profile of generation of ideas and concepts, however not really technological development. The interorganizational relationship described by the case generated ideas and aided the prototype test, but development per se was done only within the enterprise. Project 3 demonstrates that, even with incipient open innovation practices, the enterprise applies coordination mechanisms adequate to context.

As a result, we conclude that mechanisms of coordination of interorganizational relations help in the implementation of open innovation practices. The mechanisms observed in the three projects are aligned with the strategy employed by the enterprises, demonstrating they are relevant to assist in the management of this type of relationship. Moreover, the results exhibit the flexibility of such mechanisms even in distinct projects, presenting the use of mechanisms in common among them. Thus, the model developed by Grandori and Soda (1995) indicates it can be useful for the coordination of partnerships characterized by open innovation strategy. 
Considering the research suggestions of Wynarczyk et al. (2013), this paper contributes to the organizational theory about open innovation, describing how this strategy is used by SMEs. In addition, the identification of mechanisms used to coordinate collaborative projects contributes to the discussion on management of OI initiatives. The cases presented show that the use of OI practices can be supported by contracts, protecting partner enterprises from inherent risks related to this type of project.

Regarding managerial contributions, the research helped managers in the understanding of OI process in collaborative projects. The presented cases have different characteristics, demonstrating the wide range of innovative prospects for enterprises involved in collaborative practices. Even with limited resources for investments in new projects, meetings and specific teams aimed at generating new ideas and concepts favor not only the leading enterprise, but also the suppliers, clients and universities involved in these groups. Finally, open innovation gives enterprises a chance of developing new projects, be it in joint $\mathrm{R} \& \mathrm{D}$ activities, or approaching customers and suppliers.

A recommendation to entrepreneurs interested in applying the concept of open innovation is to consider both the internalization of external knowledge - as in the cases analyzed - and also the externalization of knowledge available within the enterprise. It is noticeable that enterprises usually seek to broaden data collection; however, the practice of outsourcing their technologies is less common. Rather than seeking qualification for in-house projects, enterprises can also market technologies underutilized internally, therefore increasing revenue sources through licensing or even partnerships with other enterprises that will commercially exploit such technologies.

The research came across restrictions on obtaining complementary sources of evidence for the analyzed cases, being limited to interviews with participants and secondary data collection. Another limitation refers to the data context analyzed which did not consider how previous relationships between partners might modify the use of coordination mechanisms in collaborative R\&D projects. Future studies may include this perspective in the analysis to broaden the understanding of the impact of these factors on projects. Another suggestion is to conduct longitudinal studies, monitoring collaborative projects over a period of time to understand possible changes in the coordination mechanisms according to a project stage. Carrying out new studies is another proposal to compare results identified in this research with further ones, in order to identify similar and distinct aspects for the 
construction of a theoretical model. This study serves as an inspiration for other researches on these quoted issues, so not to exhaust the discussion about the question proposed for analyzes.

\section{MECANISMOS DE COORDENAÇÃO DE PROJETOS COLABORATIVOS DE P\&D EM PEQUENAS E MÉDIAS EMPRESAS}

\section{RESUMO}

Objetivo: Analisar como ocorre a coordenação das práticas colaborativas de inovação no processo da Inovação Aberta em PMEs.

Originalidade/relevância: O estudo foi motivado por lacunas teóricas sobre a gestão de práticas colaborativas de pesquisa e desenvolvimento (P\&D) no processo da inovação aberta. A originalidade do artigo consiste em avançar na compreensão dos mecanismos que PMEs podem utilizar para gerenciar a inovação aberta e obter resultados mais efetivos.

Principais aspectos metodológicos: A pesquisa consistiu em uma abordagem qualitativa, por meio de três estudos de caso de projetos colaborativos. Foram entrevistados onze gestores envolvidos em práticas colaborativas de $\mathrm{P} \& \mathrm{D}$ nos três casos.

Síntese dos principais resultados: A formalização de mecanismos de coordenação depende da tangibilidade na aplicação dos resultados do projeto, ou seja, quanto mais próximos de ser aplicados em um novo produto, maior a importância e controle dos mecanismos de coordenação. Ainda, nos casos analisados, a definição dos mecanismos de coordenação foi estabelecida pela empresa, e não pelos parceiros externos. Da mesma forma, para as empresas entrevistadas, a busca por conhecimento externo (de fora para dentro da empresa) é mais importante para sua estratégia de $\mathrm{P} \& \mathrm{D}$ que a transferência do seu conhecimento para parceiros externos (de dentro para fora da empresa). O estudo contribui para a teoria organizacional ao relacionar as características de projetos colaborativos de $\mathrm{P} \& \mathrm{D}$ e os mecanismos de coordenação utilizados. Do ponto de vista gerencial, os resultados servem como guias para gestores 
de PMEs interessados em coordenar práticas colaborativas no processo de inovação aberta.

\section{PALAVRAS-CHAVE}

Mecanismos de coordenação. Inovação aberta. Práticas colaborativas. Pesquisa e desenvolvimento. Pequenas e médias empresas.

\section{REFERENCES}

Axelrod, R. (2010). A evolução da cooperação. São Paulo: Leopardo Editora.

Barbosa, D. H., \& Musettib, M. A. (2012). Levantamento do desempenho logístico das PMEs da indústria de bens de capital: Uma análise comparativa. Production, 22 (2), 249-258.

Bardin, L. (1995). Análise de conteúdo. Lisboa: Edições.

Borini, F. M., Pereira, R. M., \& Rosseto, D. E. (2016). O Impacto da Cooperação com Parceiros de Mercado e de Pesquisa na Inovação de Produto e Processo das Empresas Brasileiras. Proceedings of the Encontro Nacional da ANPAD, Costa do Sauipe, BA, 40.

Brass, D. J., Galaskiewicz, J., Greve, H. R., \& Tsai, W. (2004). Taking stock of networks and organizations: A multilevel perspective. Academy of Management Journal, 47(6), 795-817.

Brunswicker, S., \& Vanhaverbeke, W. (2015). Open innovation in small and medium - sized enterprises (SMEs): External knowledge sourcing strategies and internal organizational facilitators. Journal of Small Business Management, 53(4), 1241-1263.

Carvalho, E., \& Sugano, J. (2016). Tipologias de inovação aberta em novas empresas de base tecnológica brasileiras. Revista Portuguesa e Brasileira de Gestão, 15(2), 65-83.

Chesbrough, H. (2012). Inovação aberta: como criar e lucrar com a tecnologia. Porto Alegre: Bookman.

Chiaroni, D., Chiesa, V., \& Frattini, F. (2011). The open innovation journey: How firms dynamically implement the emerging innovation management paradigm. Technovation, 31(1), 34-43. 
Christensen, C. M. (2001). O dilema da inovação: Quando novas tecnologias levam empresas ao fracasso. São Paulo: Makron.

Cropper, S., Ebers, M., Huxham, C., \& Ring, P. S. (2008) Introducing interorganizational relations. In S. Cropper, M. Ebers, C. Huxham, \& P. S. Ring (Eds.), The Oxford handbook of inter-organizational relations (pp. 3-24). New York: Oxford University Press.

Dahlander, L., \& Gann, D. M. (2010). How open is innovation? Research policy, 39(6), 699-709.

Dodgson, M., Gann, D., \& Salter, A. (2006). The role of technology in the shift towards open innovation: The case of Procter \& Gamble. R\&D Management, 36(3), 333-346.

Dyer, J. H., \& Nobeoka, K. (2000). Creating and managing a high-performance knowledge-sharing network: The Toyota case. Strategic Management Journal, $21(3), 345-367$.

Enkel, E., Gassmann, O., \& Chesbrough, H. (2009). Open R\&D and open innovation: exploring the phenomenon. R\&D Management, 39(4), 311-316.

Escrivão Filho, E., Albuquerque, A. F., Nagano, M. S., Junior, L. A. P., \& Oliveira, J. (2017). Identifying SME mortality factors in the life cycle stages: an empirical approach of relevant factors for small business ownermanagers in Brazil. Journal of Global Entrepreneurship Research, 7(5), 1-15.

Etzkowitz, H., Solé, F., \& Piqué, J. M. (2007). The creation of born global companies within the science cities: An approach from triple helix. Engevista, 9(2), 149-164.

Freel, M., \& Robson, P. J. (2016). Appropriation strategies and open innovation in SMEs. International Small Business Journal, 35(5), 578-596

Freeman, C. (1992). Formal scientific and technical institutions in the national system of innovation. In B. Lundvall (Ed.), National systems of innovation: towards a theory of innovation and interactive learning (pp. 169187). London: Pinter.

Gassmann, O., Enkel, E., \& Chesbrough, H. (2010). The future of open innovation. R\&D Management, 40(3), 213-221.

Grandori, A., \& Soda, G. (1995). Inter-firm networks: Antecedents, mechanisms and forms. Organization Studies, 16(2), 183-214.

Håkansson, H. (1990). Technological collaboration in industrial networks. European Management Journal, 8(3), 371-379.

Hardy, C., Phillips, N., \& Lawrence, T. B. (2003). Resources, knowledge and influence: The organizational effects of interorganizational collaboration. Journal of Management Studies, 40(2), 321-347. 
Hasnas, I., Lambertini, L., \& Palestini, A. (2014). Open Innovation in a dynamic Cournot Duopoly. Economic Modelling, 36, 79-87.

Huizingh, E. K. (2011). Open Innovation: State of the art and future perspectives. Technovation, 31(1), 2-9.

Instituto Brasileiro de Geografia e Estatística. (2016). Pesquisa de Inovação PINTEC: Edições (2014). Retrieved from https://www.ibge.gov.br/ estatisticas-novoportal/multidominio/ciencia-tecnologia-e-inovacao/ 9141-pesquisa-de-inovacao.html

Jong, J. P., Vanhaverbeke, W., Kalvet, T., \& Chesbrough, H. (2008). Policies for open innovation: Theory, framework and cases. Helsinki: Tarmo Kalvet.

Keupp, M. M., \& Gassmann, O. (2009). Determinants and archetype users of open innovation. R\&D Management, 39(4), 331-341.

Laursen, K., \& Salter, A. (2006). Open for innovation: the role of openness in explaining innovation performance among UK manufacturing firms. Strategic Management Journal, 27(2), 131-150.

Lorenzoni, G., \& Ornati, O. A. (1988). Constellations of firms and new ventures. Journal of Business venturing, 3(1), 41-57.

Malhotra, N. K., Birks, D. F., \& Wills, P. (2012). Market Research. New York: FT Press.

Manning, S. (2017). The rise of project network organizations: Building core teams and flexible partner pools for interorganizational projects. Research Policy, 46(8), 1399-1415.

Minayo, M. C. S. (2000) O desafio do conhecimento, pesquisa quantitativa em saúde. São Paulo: Hucitec-Abrasco.

Nooshinfard, F., \& Nemati-Anaraki, L. (2014). Success factors of interorganizational knowledge sharing: A proposed framework. The Electronic Library, 32(2), 239-261.

Nooteboom, B. (1996). Trust, opportunism and governance: A process and control model. Organization Studies, 17(6), 985-1010.

Nuvolari, A. (2004). Collective invention during the British Industrial Revolution: The case of the Cornish pumping engine. Cambridge Journal of Economics, 28(3), 347-363.

Pavitt, K. (1992). Some foundations for a theory of the large innovation firm. In G. Dosi, R. Giannetti, \& P. Toninelli (Eds), Technology and enterprise in a historical perspective (pp 212-228). Oxford: Clarendon Press.

Phillips, N., Lawrence, T. B., \& Hardy, C. (2000). Inter-organizational collaboration and the dynamics of institutional fields. Journal of Management Studies, 37(1), 23-43. 
Radas, S., \& Bozic, L. (2012). Overcoming failure: Abandonments and delays of innovation projects in SMEs. Industry and Innovation, 19(8), 649-669.

Rasera, M., \& Balbinot, Z. (2010). Redes de inovação, inovação em redes e inovação aberta: Um estudo bibliográfico e bibliométrico da produção científica no ENANPAD 2005-2009 sobre inovação associada a redes. Análise - Revista de Administração da PUCRS, 21 (2), 127-136.

Ring, P. S., \& Van de Ven, A. H. (1994). Developmental processes of cooperative interorganizational relationships. Academy of Management Review, 19(1), 90-118.

Rodan, S., \& Galunic, C. (2004). More than network structure: How knowledge heterogeneity influences managerial performance and innovativeness. Strategic Management Journal, 25(6), 541-562.

Serviço Brasileiro de Apoio às Micro e Pequenas Empresas. (2013). Anuário do Trabalho na Micro e Pequena Empresa. Retrieved from http://www.sebrae. com.br/Sebrae/Portal\%20Sebrae/Anexos/Anuario\%20do\%20Trabalho\% 20Na\%20Micro\%20e\%20Pequena\%20Empresa_2013.pdf

Seran, T., Pellegrin-Boucher, E., \& Gurau, C. (2016). The management of coopetitive tensions within multi-unit organizations. Industrial Marketing Management, 53, 31-41.

Spithoven, A., Vanhaverbeke, W., \& Roijakkers, N. (2013). Open innovation practices in SMEs and large enterprises. Small Business Economics, 41 (3), 537-562.

Tödtling, F., Lehner, P., \& Kaufmann, A. (2009). Do different types of innovation rely on specific kinds of knowledge interactions? Technovation, 29(1), 59-71.

Triviños, A. (1987). Introdução à pesquisa em ciências sociais: A pesquisa qualitativa em educação. São Paulo: Atlas.

Vanhaverbeke, W., \& Chesbrough, H. (2014). A classification of open innovation and open business models. In H. Chesbrough, W. Vanhaverbeke, \& J. West (Eds.), New frontiers in Open Innovation (pp. 50-68). Oxford: Oxford University Press.

Vlaar, P. W., Van Den Bosch, F. A., \& Volberda, H. W. (2007). Towards a dialectic perspective on formalization in interorganizational relationships: How alliance managers capitalize on the duality inherent in contracts, rules and procedures. Organization Studies, 28(4), 437-466.

Vrande, V. de, Jong, J. P. de, Vanhaverbeke, W., \& Rochemont, M. de. (2009). Open innovation in SMEs: Trends, motives and management challenges. Technovation, 29(6), 423-437. 
Williamson, O. E. (1985). The economic institutions of capitalism. New York: Simon and Schuster.

Wynarczyk, P., Piperopoulos, P., \& McAdam, M. (2013). Open innovation in small and medium-sized enterprises: An overview. International Small Business Journal, 31 (3), 240-255.

Yin, R. K. (2001). Estudo de Caso: Planejamento e Métodos. Porto Alegre: Bookman.

\section{AUTHOR NOTE}

Daniela Baggio, Escola de Gestão e Negócios, Universidade do Vale do Rio dos Sinos (Unisinos), ORCID:0000-0001-5811-6135; Douglas Wegner, Escola de Administração, Universidade Federal do Rio Grande do Sul (UFRGS), ORCID:0000-0001-8634-5971; and Gustavo Dalmarco, Escola de Administração, Universidade Federal do Rio Grande do Sul (UFRGS), ORCID:00000001-6347-5562.

Daniela Baggio is now at Programa de Pós-graduação em Administração, Universidade do Vale do Rio dos Sinos (Unisinos); Douglas Wegner is now Assistant Professor at Universidade do Vale do Rio dos Sinos (Unisinos).

Correspondence concerning this article should be addressed to Daniela Baggio, Avenida Dr. Nilo Peçanha, 1600, Bairro Boa Vista, Porto Alegre, RS, Brazil, CEP 91330-002.

EDITORIAL BOARD

Editor-in-chief

Silvio Popadiuk

Associated Editor

Thais Vick

Technical Support

Vitória Batista Santos Silva
EDITORIAL PRODUCTION

Publishing Coordination

Irina Migliari

Language Editor

Editorial Trainee

Maria Luiza Vanz

Copyeditor

Irina Migliari
Daniel Leão

Layout Designer

Emap

Graphic Designer

Libro 